\title{
Kadar interleukin-17 (IL-17) serum berkorelasi dengan rasio receptor activator of NF-KB ligand/osteoprotegerin (RANKL/OPG) pada penderita Sistemik Lupus Eritematosus
}

\author{
Tonny ${ }^{1}$, Gede Kambayana ${ }^{2}$, Tjokorda Raka Putra ${ }^{2}$, Pande Ketut Kurniari ${ }^{2}$
}

\footnotetext{
${ }^{1}$ Program Studi Pendidikan Dokter Spesialis Penyakit Dalam, Fakultas Kedokteran Universitas Udayana/ RSUP Sanglah, Denpasar, Bali, Indonesia

${ }^{2}$ Departemen/KSM Penyakit Dalam, Fakultas Kedokteran Universitas Udayana/RSUP Sanglah, Denpasar, Bali, Indonesia Korespondensi : Tonny/ tonny.doctor@gmail.com
}

Background : Inflammation process involved in the pathogenesis of SLE. The inflammation process which occurred in patients with SLE also affect the differentiation of osteoclast and osteoblast. Interleukin-17 (IL-17) is a pro-inflammatory mediator which produced due to systemic inflammatory process. The increase of pro-inflammatory cytokine resulted in impairment of RANKL regulation, which affect osteoprotegerin (OPG). The increase of pro-inflammatory cytokine in patients with SLE may resulted in imbalance ratio of RANKL/OPG.

Objective : Determine the correlation between serum IL-17 levels with ratio of RANKL/OPG in patients with SLE.

Method : This was an observational analytical cross-sectional study conducted at outpatient clinic and inpatient ward of Internal Medicine of Sanglah Hospital Denpasar, Bali, Indonesia from January to March 2018. Sample were female SLE patients with age more than 18 years, not menopause and agree to participate. High sensitivity ELISA (Enzymelinked immunosorbent assay) performed to analyze serum IL-17 levels. RANKL measured with Human sRANKL (TOTAL) ELISA method, while OPG measured with Human Osteoprotegerin ELISA method. Ratio of RANKL/OPG obtained from comparation of RANKL and OPG.

Result : 68 subjects were involved in this study with median of age was 31.32 (17-54). The IL-17 levels and ratio of RANKL/OPG in all subjects was 0.435 (0.23-30.65) and 70.18 (4.98-1060.46), respectively. Significant correlation was found between IL-17 with ratio of RANKL/OPG $(p=0.010)$. The result of multivariate analysis obtained serum IL-17 correlated with ratio of RANKL/OPG $(B=6,554, \operatorname{SE}(B)=2,686, p=0,018)$.

Conclusion : There was correlation between IL-17 serum with ratio of RANKL/OPG in patients with SLE.

Keywords : SLE, inflammation, cytokine, IL-17, RANKL, OPG

Latar belakang : Proses inflamasi berperan penting dalam patogenesis SLE. Proses inflamasi yang terjadi pada penderita SLE juga akan mempengaruhi diferensiasi osteoklas dan osteoblast. Interleukin-17 (IL-17) merupakan mediator pro-inflamasi yang dihasilkan akibat proses inflamasi sistemik. Peningkatan kadar sitokin pro-inflamasi diketahui mengakibatkan perubahan regulasi RANKL, yang selanjutnya akan mempengaruhi osteoprotegerin (OPG). Peningkatan kadar sitokin pro-inflamasi pada penderita SLE dapat mengakibatkan ketidakseimbangan RANKL/OPG. Tujuan : Mengetahui korelasi antara kadar IL-17 serum dengan rasio RANKL/OPG pada penderita SLE.

Metode : Penelitian ini merupakan studi observasional analitik potong lintang yang dilakukan di poliklinik dan bangsal rawat inap. Penyakit Dalam RSUP Sanglah Denpasar, Bali, Indonesia dari bulan Januari-Maret 2018. Penderita SLE berjenis kelamin wanita yang berusia lebih dari 18 tahun dan belum mengalami menopause serta bersedia mengikuti penelitian dengan menandatangani informed consent diikutsertakan dalam penelitian. Kadar IL-17 serum diperiksa dengan menggunakan metode high sensitivity ELISA (Enzyme-linked immunosorbent assay). RANKL diukur menggunakan metode Human sRANKL (TOTAL) ELISA, sedangkan OPG diukur menggunakan metode Human Osteoprotegerin ELISA. Rasio RANKL/OPG didapatkan dari perbandingan antara kadar RANKL dan OPG.

Hasil : Penelitian ini melibatkan 68 subyek penelitian. Median umur subyek penelitian yaitu 31,32 (17-54). Kadar IL-17 dan rasio RANKL/OPG pada seluruh subyek yaitu 0,435 (0,23-30,65) dan 70,18 (4,98-1060,46). Didapatkan korelasi yang bermakna antara kadar IL-17 dan rasio RANKL/OPG dengan $p=0,010$. Dari analisis multivariat didapatkan bahwa kadar IL-17 berkorelasi dengan rasio RANKL/OPG $(B=6,554, S E(B)=2,686, p=0,018)$.

Simpulan : Pada penelitian ini terdapat korelasi antara kadar IL-17 serum dengan rasio RANKL/OPG pada penderita SLE.

Kata Kunci : SLE, inflamasi, sitokin, IL-17, RANKL, OPG
Tanggal Disetujui : 4 Mei 2018

Tanggal Diterbitkan : 10 Mei 2018 


\section{PENDAHULUAN}

Sistemik Lupus Eritematosus (SLE) adalah penyakit autoimun sistemik yang kompleks ditandai dengan adanya autoantibody terhadap inti sel dan melibatkan banyak sistem organ dalam tubuh. Etiologi SLE diduga melibatkan interaksi yang kompleks dan multifaktorial antara variasi genetik dan factor lingkungan. Prevalensi penderita SLE terus meningkat dan diperkirakan sekitar 20-150 kasus per 100.000 populasi. ${ }^{1}$

Osteoporosis merupakan salah satu komplikasi kronis dari SLE. Penyebab osteoporosis pada penderita SLE dapat disebabkan karena berkurangnya aktivitas hidup, gangguan fungsi ginjal, disfungsi endokrin, serta penggunaan terapi jangka panjang glukokortikoid. Selain itu, proses inflamasi juga diketahui berperan dalam timbulnya komplikasi osteoporosis pada penderita SLE. ${ }^{2}$

Peranan imunopatogenesis yang memicu timbulnya manifestasi klinis SLE melibatkan berbagai sitokin proinflamasi seperti interferon- $\alpha$ (IFN- $\alpha$ ), interferon- $\gamma$ (IFN- $\gamma$ ), dan interleukin-17 (IL-17). Beberapa penelitian menunjukkan bahwa IL-17 memegang peranan dalam patogenesis SLE. Kadar IL-17 serum penderita SLE lebih tinggi dibandingkan dengan orang normal serta berkorelasi dengan aktifitas penyakit. ${ }^{3}$

Interleukin-17 sebagai sitokin proinflamasi yang dihasilkan oleh Th 17 akan merangsang sel $\mathrm{T}$ untuk mengeluarkan mediator-mediator proinflamasi yang lain seperti interleukin-1 (IL-1), interleukin-6 (IL-6), dan tumor necrosis factor- $\alpha$ (TNF- $\alpha$ ) serta kemokin. IL-1 dan TNF- $\alpha$ yang dihasilkan pada proses inflamasi akan merangsang osteoblas untuk mengekspresikan receptor activator of nuclear factor-kappa B ligand (RANKL), protein membran tipe II yang diekspresikan oleh sel-sel seri osteogenik, serta menghambat produksi osteoprotegerin (OPG), OPG adalah anggota super famili reseptor TNF yang tidak memiliki domain transmembran sehingga akan disekresikan ke dalam sirkulasi. Ekspresi OPG akan menghambat resorpsi tulang yang fisiologik maupun patologik. Pengaruh IL-1 dan TNF- $\alpha$ juga meningkatkan diferensiasi makrofag menjadi osteoklas. Proses inflamasi mempengaruhi diferensiasi osteoklas dan osteoblas sehingga menyebabkan kondisi yang tidak seimbang antara resorpsi tulang dan formasi tulang. ${ }^{4}$

Penelitian tentang peranan interleukin-17 dalam proses osteoporosis pada penderita SLE masih sangat terbatas. Penelitian ini bertujuan untuk mengetahui hubungan antara kadar interleukin-17 serum dengan rasio RANKL/OPG pada penderita SLE.

\section{METODE}

\section{Desain penelitian}

Penelitian ini menggunakan rancangan observasional analitik potong lintang. Penelitian dilakukan di poliklinik dan bangsal rawat inap Penyakit Dalam RSUP Sanglah Denpasar. Penelitian ini akan dilakukan bulan Januari hingga Maret 2018. Populasi target adalah semua penderita SLE yang menjalani perawatan. Populasi terjangkau adalah semua penderita SLE yang menjalani perawatan di Poliklinik dan Ruang Rawat Inap Penyakit Dalam RSUP Sanglah Denpasar. Penderita SLE berjenis kelamin wanita yang berusia lebih dari 18 tahun dan belum mengalami menopause serta bersedia mengikuti penelitian dengan menandatangani informed consent diikutsertakan dalam penelitian ini. Penderita SLE dengan penyakit diabetes melitus, keganasan, penyakit jantung koroner, penyakit ginjal kronik stadium $\mathrm{V}$ dengan hemodialisis (HD), obesitas, infeksi, menopause, dan tidak bersedia mengikuti penelitian diekslusi pada penelitian ini. Sistemik lupus eritematosus didiagnosis dengan anamnesis, pemeriksaan fisik dan penunjang sesuai kriteria ARA yang dimodifikasi tahun 1997 berdasarkan data primer atau rekam medis. ${ }^{5}$

Besar sampel pada penelitian ini sebesar 68 sampel, dengan kesalahan tipe $1(\alpha)$ ditetapkan sebesar $5 \%$, kesalahan tipe 2 ( $\beta$ ) ditetapkan sebesar 10\%. Variabel independen adalah kadar interleukin-17 serum, sedangkan variabel dependen adalah rasio RANKL/OPG.

\section{Analisis laboratorium}

Kadar IL-17 serum yang diperiksa pada penelitian ini merupakan interleukin-17A manusia yang diperiksa dengan menggunakan metode high sensitivity ELISA (Enzymelinked immunosorbent assay) dan kit IL-17A HS (eBioscience). RANKL didefenisikan sebagai kadar total sRANKL (yang bebas dan berikatan) pada serum yang diukur menggunakan metode Human sRANKL (TOTAL) ELISA, dengan alat The RD.193004200R Human sRANKL (total) ELISA Kit yang diproduksi oleh BioVendor-Laboratorni medicine a.s. Sampel diambil dari darah perifer. OPG didefenisikan sebagai kadar osteoprotegerin pada serum yang diukur menggunakan metode Human Osteoprotegerin ELISA, dengan alat The RD.194003200 Human Osteoprotegerin ELISA Kit yang diproduksi oleh BioVendor-Laboratorni medicine a.s. Sampel diambil dari darah perifer. Rasio RANKL/OPG adalah perbandingan antara kadar RANKL dan OPG.

\section{Analisis statistik}

Untuk data karakteristik subjek penelitian dilakukan analisis deskriptif dan dinyatakan dalam rerata dan simpang baku bila data berdistribusi normal atau dalam median dan nilai minimum maksimum bila tidak berdistribsi normal. Uji korelasi dilakukan dengan uji Pearson atau uji Spearman. Analisa regresi dipakai untuk mencari hubungan linier antara variabel dependen (sumbu y) dan variabel independen (sumbu 
$\mathrm{x})$. Tingkat kemaknaan $(\alpha)$ penelitian ini ditetapkan pada nilai probabilitas (p) kurang dari 0,05.

\section{HASIL PENELITIAN}

Penelitian ini melibatkan 68 subyek penelitian, dengan median umur yaitu 31,32 (17-54). Karakteristik dasar subyek penelitian dapat dilihat pada Tabel 1.

Tabel 1. Karakteristik subyek penelitian

\begin{tabular}{lll}
\hline Karakteristik & Nilai & $\%$ \\
\hline Umur (tahun) & $31,32(17-54)$ & \\
Jenis Kelamin & & 0 \\
$\quad$ Laki-laki & 0 & 100 \\
$\quad$ Perempuan & 68 & \\
Indeks massa tubuh $\left(\mathrm{kg} / \mathrm{m}^{2}\right)$ & $21,67 \pm 3,08$ & \\
& & \\
Laju Endap Darah & $32,25(4,3-139,7)$ & \\
C-Reactive Protein & $8,99(0,08-236,81)$ & \\
Dosis Prednison (gram) & $9,49(1-40)$ & \\
Durasi Sakit (bulan) & $24,63(1-120)$ & \\
MEX-SLEDAI & $0,81(0-7)$ & \\
Kadar IL-17 (pg/mL) & $0,435(0,23-30,65)$ & \\
Rasio RANKL/OPG & $70,18(4,98-1060,46)$ & \\
\hline
\end{tabular}

RANKL: receptor activator of nuclear factor-kappa $B$ ligand, $O P G$ : osteoprotegerin

Pada penelitian ini didapatkan korelasi yang bermakna antara kadar IL-17 dan rasio RANKL/OPG dengan $\mathrm{p}=0,010$. Persamaan linearnya yaitu IL-17 $=(6,988 \times$ rasio RANKL/ OPG) + 102,495.

Untuk mengetahui pengaruh variabel kontrol yaitu umur, durasi sakit, dosis steroid, dan skor MEX-SLEDAI terhadap korelasi antara kadar IL-17 dengan rasio RANKL/ OPG maka dilakukan analisis regresi linier. Analisis yang dilakukan didapatkan bahwa kadar IL-17 berkorelasi dengan rasio RANKL/OPG $(\mathrm{B}=6,554, \mathrm{SE}(\mathrm{B})=2,686, \mathrm{p}=0,018)$.

Tabel 2. Analisis multivariat rasio RANKL/OPG dengan variabel lain

\begin{tabular}{lcccc}
\hline Parameter & B & Std. Error & t & Sig. \\
\hline Intercept & 256,987 & 98,850 & 2,600 & 0,012 \\
IL-17 (pg/mL) & 6,554 & 2,686 & 2,440 & $\mathbf{0 , 0 1 8}$ \\
Umur (tahun) & $-3,785$ & 2,435 & $-1,555$ & 0,125 \\
Durasi sakit (bulan) & $-1,785$ & 1,165 & $-1,531$ & 0,131 \\
Dosis steroid (gram) & 1,183 & 4,510 & 0,262 & 0,794 \\
Skor MEX-SLEDAI & $-2,341$ & 10,931 & $-0,214$ & 0,831 \\
\hline
\end{tabular}

\section{DISKUSI}

Penelitian ini melibatkan 68 subyek penelitian penderita SLE yang berobat jalan atau yang rawat inap di RSUP Sanglah. Dari 68 subyek penelitian, didapatkan jumlah perempuan sebanyak 68 orang (100\%). Persentase ini sesuai dengan prevalensi penderita dengan SLE yang lebih banyak pada perempuan dibandingkan dengan laki-laki. Penelitian oleh Jakes (2010) didapatkan rasio laki-laki dan perempuan dapat mencapai $1: 10{ }^{6}$

Pada penelitian ini median usia penderita SLE adalah 31,32 tahun dengan rentang 17-54 tahun. Median usia ini hampir sama dengan yang didapatkan Sheane dkk (2010) yaitu 34,3 tahun dimana insiden puncak SLE terjadi pada usia produktif antara 15 sampai 40 tahun.

Kadar IL-17 pada penderita SLE didapatkan dengan median 0,435 (0,23-30,65) pg/mL. Hasil ini lebih rendah daripada hasil yang didapat dari beberapa penelitian sebelumnya oleh Warren Raymond, dkk (2017) 28,4 pg/mL. Sebagian besar penelitian yang telah ada mendapatkan kadar IL-17 pada penderita SLE lebih tinggi dibandingkan pada populasi umum.

Hasil analisis korelasi kadar IL-17 dan rasio RANKL/ OPG menunjukkan hasil terdapat hubungan antara keduanya pada penderita SLE. Penelitian Diana pada tahun 2011 yang membandingkan antara 103 penderita SLE dan 114 populasi normal menunjukkan bahwa pada penderita SLE memiliki densitas massa tulang yang lebih rendah. ${ }^{7}$ Walaupun kadar RANKL tidak berbeda antara 2 kelompok tersebut, Penelitian Molnar menunjukkan korelasi antara kadar IL-17 dengan hasil bone densitometri pada wanita post menopause $(\mathrm{p}<0,008 \mathrm{r}=$ $-0,279)$ dan korelasi positif dengan kadar RANKL ( $\mathrm{p}<0,0001$ $\mathrm{r}=0,387$ ).

Beberapa penelitian menunjukkan bahwa IL-17 memegang peranan dalam patogenesis SLE. Kadar IL-17 serum penderita SLE lebih tinggi dibandingkan dengan orang normal serta berkorelasi dengan aktifitas penyakit. Peningkatan produksi IgG total, anti-dsDNA IgG dan IL-6 oleh sel mononuklear darah tepi penderita SLE berkaitan dengan IL-17. ${ }^{3}$ IL-17 merupakan sitokin dari sel T aktif dan berperan pada produksi prostaglandin $\mathrm{E}_{2}$ dan IL-6 oleh sel stromal sumsum tulang. Peningkatan kadar sitokin proinflamasi seperti TNF- $\alpha$, IL-1, IL-6, dan IL-17 pada penderita SLE dapat menginduksi RANKL untuk mengakselerasi proses osteoklastogenesis. ${ }^{8}$

Penelitian ini memiliki beberapa kelemahan. Penelitian ini tidak membandingkan kadar IL-17 serum dan rasio RANKL/OPG dengan individu sehat. Keterbatasan pada penelitian ini adalah perlu adanya pemeriksaan kadar IL-17 serum dan rasio RANKL/OPG pada kontrol orang sehat sebagai pembanding. 


\section{SIMPULAN}

Terdapat korelasi antara kadar IL-17 serum dengan rasio RANKL/OPG pada penderita SLE.

\section{DAFTAR PUSTAKA}

1. Peter HS, Bevra HH, David SP, Monica RC. Epidemiology and pathogenesis of systemic lupus erythematosus. UpToDate 2016.

2. Sinigaglia L, et al. Bone mass in systemic lupus erythematosus. Clin Exp Rheumatol 2000:18(Suppl 21):527-534.

3. Nalbandian A, et al. Interleukin-17 and systemic lupus erythematosus: current concepts. Clinical and Experimental Immunology; 2009:157:209-215.

4. Bezerra MC, Carvalho JF, Prokopowitsch AS, Pereira RMR. RANK, RANKL and osteoprotegerin in arthritic bone loss. Brazillian Journal of Medical and Biological Research; 2005:38:161-170.

5. Isbagio H, Albar Z, Kasjmir YI, Setiyohadi B. Lupus eritematosus sistemik, Dalam: Sudoyo AW, Setiyohadi B, Alwi I,Simadibrata M, Setiati S. (eds). Buku Ajar Ilmu
Penyakit Dalam. Edisi 4. Jakarta: Interna Publishing. 2008: 1224-1231.

6. Jakes RW, Bae SC, Louthrenoo W, Mok C, Navarra S, Kwon N. Systematic review of the epidemiology of systemic lupus erythematosus in the asia-pacific region: prevalence, incidence, clinical features, and mortality. Arthritis Care \& Research; 2012:64 (2):159-168.

7. Diana CF, et al. Soluble receptor activator of nuclear factor $x \mathrm{~B}$ ligand / osteoprotegerin ratio is increased in systemic lupus erythematosus patients. Arthritis Research \& Therapy 2011; 13:175.

8. Amarasekara DS, et al. Bone loss triggered by the cytokine network in inflammatory autoimmune diseases. Journal of Immunology Research 2014;8:32-127.

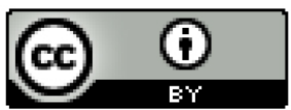

This work is licensed under a Creative Commons Attribution 4.0 International License. 